\title{
Practice what you Preach? Limitations to Imposing Democratic Norms on NGos
}

\author{
Martine Beijerman \\ Amsterdam Center for International Law, University of Amsterdam \\ m.beijerman@uva.nl
}

\begin{abstract}
This paper challenges the scholarly tendency of imposing democratic norms on nongovernmental organisations (NG Os). For decades there has been a strong debate among International Relations and International Law scholars on the question of whether or not NG Os contribute to the democratic legitimacy of international law. Notwithstanding different arguments, both critics of and adherents seem to be primarily occupied with theorising and criticising the internal democratic legitimacy of NGOs. In this article I question whether this is justifiable. Imposed democratic norms conflict with the inherent unpredictable character of NGOs. Whereas the unpredictability of NGOs in terms of form and content is often perceived as unreliable, it characterises their essential voluntariness, which can be considered their main contribution to democracy.
\end{abstract}

\section{Keywords}

democratic legitimacy - Non-Governmental Organisations - international lawmaking - representation - accountability

Law shapes the lives of individuals, obliging them to undertake certain actions or to refrain from undertaking action by using the right to issue commands and

* This article is based on the PhD research I have conducted under the supervision of Prof. Jean D'Aspremont and Dr. Aernout Nieuwenhuis, and defended on 16 May 2016 at the University of Amsterdam.

(C) MARTINE BEIJERMAN, 2018 | DOI 10.1163/18719732-12341364

This is an open access article distributed under the terms of the prevailing CC-BY-NC license at the time of publication. 
enforce these commands. In democratic societies, the subjects of law traditionally find this far-reaching exercise of authority acceptable, as long as they can equally determine the content of it. Acceptability means here as much as recognising the 'right to rule' of a public authority. ${ }^{1}$ It is upon this condition that laws are deemed democratically legitimate.

International law is often criticised for not living up to the promise of democratic legitimacy. ${ }^{2}$ One of the proposed remedies for the democratic deficits of international law concerns the participation of NGOs in international lawmaking. ${ }^{3}$ For the sake of this article, I call this proposition the 'NGO democratic legitimacy thesis'. Interestingly, together with the claim that NGOs contribute to the democratic legitimacy of international law comes the assumption that they only can do so, when they are democratically organised themselves. ${ }^{4}$

1 Seymour Martin Lipset, "The Social Requisites of Democracy Revisited: 1993 Presidential Address", 59(1) American Sociological Review (1994) p. 7; Allen Buchanan, "The Legitimacy of International Law" in S. Besson, and J. Tasioulas (eds.), The Philosophy of International Law (2010) p. 79; Joseph Raz, The Morality of Freedom (1986) pp. 25-28.

2 Philip Allott, “Intergovernmental societies and the idea of constitutionalism”, in J. M. Coicaud and V. Heiskanen (eds.), The Legitimacy of International Organizations (2001) p. 69; Nico Krisch, "International Law in Times of Hegemony: Unequal power and the Shaping of the International Legal Order", 16(3) European Journal of International Law (2005) p. 369; Eyal Benvenisti, "The Emergence of Global Governance and the Corresponding Need to Regulate it", 3 The Global Trust Working Paper Series (2014) p. 3, referring to Sabine Cassese, The Global Polity: Global Dimensions Of Democracy And The Rule Of Law (2012). See also David Livshiz, "Updating American Administrative Law: WTO, International Standards, Domestic Implementation and Public Participation", 24(4) Wisconsin International Law Journal (2006) p. 998; Samantha Besson and John Tasioulas, "Introduction", The Philosophy of International Law (2010); Ferenc Miszlivetz, "Lost in Transformation: The Crisis of Democracy and Civil Society", in M. Kaldor, H.L. Moore, S. Selchow, and T. Murray-Leach (eds.), Global Civil Society 2012: Ten Years of Critical Reflection (2012) p. 68; Rob Walker, Inside/Outside: International Relations as Political Theory (1993) p. 143.

3 See Peter Spiro, "Accounting for NGOs", 3(1) Chicago Journal of International Law (2002); Susan Marks and James Crawford, "The Global Democracy Deficit: An Essay in International Law and Its Limits", in D. Held, M. Köhler and D. Archibugi (eds.), Re-imagining Political Community: Studies in Cosmopolitan Democracy (1998) p. 72; Menno Kamminga, "The Evolving Status of NGOs under International Law, a Threat to the Inter-State System?", in P. Alston (ed.), Non-State Actors and Human Rights (2005) p. 83.

4 These democratic norms go beyond the general legal obligations NG Os are subjected to under domestic law: they have to obey existing laws and regulations, cannot engage in illegal activities, nor can they violate constitutional guarantees or rights without risking judicial sanctions. Enrique Peruzzotti, "Democratic Credentials or Bridging Mechanisms? Constituents, Representatives, and the Dual Politics of Democratic Representation", in E. Erman and 
In this paper I assess the validity of this assumption. I aim to substantiate and further develop the work of, among others, Charnovitz and Peruzzotti, ${ }^{5}$ by discussing different concerns that allow us to question the imposition of democratic norms on NGOS. Section 2 introduces the practice of NGO participation in international law-making. Section 3 addresses some of the core elements of the NGO democratic legitimacy thesis. Section 4 sets out the democratic expectations towards NGOs that dominate the debate on the NGO democratic legitimacy thesis. Section 5 argues that an external standardisation is complicated by the inherent voluntariness and indeterminacy of NGOs. Section 6 discusses the consequences of scholarly attempts to 'govern' NGOs by imposing democratic norms. Section 7 further specifies these governing attempts by focusing on the tendency to describe NGOS in content-independent procedural terms. Section 8 touches upon the pitfalls of prioritising a focus on NGOs' democratic legitimacy, compared to the relative silence on what is required of the international political constellation in terms of institutional and social preconditions for any democratic legitimation of international law is possible.

NGOs form a heterogeneous object of study, organised in different ways and set up with different aims and functions. Therefore, I take some of their common similarities in 'form' as a starting point: NGOs are a collective of individuals by people who have voluntarily formed an organisation, not for profit, independent from governments. They are formally registered by a state, and adopt non-violent approaches to their work. ${ }^{6}$ The specific type of NGO that is object of inquiry here exercises influence on international law-making processes by strategically persuading states and international organisations to enact new norms or to change old ones. ${ }^{7}$

A. Uhlin (eds.), Legitimacy Beyond the State? Re-examining the Democratic Credentials of Transnational Actors (2010) p. 165 .

5 Steve Charnovitz, "Accountability of Nongovernmental Organizations (NGOs) in Global Governance", GWU Law School Public Law Research Paper No. 145 (2005) p. 36. Peruzzotti, supra note 4, p. 163 .

6 Patrick Kilby, "Accountability for Empowerment: Dilemmas Facing Non-Governmental Organizations", 34(6) World Development (2006) p. 952.

7 There are many other roles NGOs take up in international governance. NGOs carry out many services that government and the private sector are ill equipped or disinclined to do. In this article, I limit myself to NGOs involvement in international law-making, as this capacity is central to the NGO democratic legitimacy thesis. 
International law-making knows different stages: norm emergence, norm cascade and norm internalisation. ${ }^{8}$ The NGO democratic legitimacy thesis oscillates between the first two stages. First the actors object of the thesis are the NGOs, led by norm entrepreneurs, that push the adoption of a certain norm, out of humanity concerns or out of commitment to specific beliefs. Often, they have to compete with, and contest other norms. The switch from norm emergence and norm cascade might take up more than eighty years, as the domestic and international advocacy for women's suffrage has taught us. ${ }^{9}$ The intended norm cascade by NGOs occurs under the auspices of states and international organisations that, after embracing the new norm, instigate other states to do so as well. NGOs try to assure the support of states in different ways, using different tactics, including but not limited to agenda setting, problem definition, information provision, advocacy and mobilisation, lobbying, direct participation in the formulation of new norms, and monitoring nation-state enforcement of principles and norms. ${ }^{10} \mathrm{NGO}$ engage both their supporters and their constituency by their concerns and values that generally are presented to have a public benefit purpose. ${ }^{11}$

Since 1948, emergent norms have increasingly become institutionalised in international law. The participation of NGOS in international law-making itself is nothing new. ${ }^{12}$ One of the frontrunners was the Institut de Droit International, founded in 1873 , that presented the idea to establish a court of arbitration and prepared several significant treaties. ${ }^{13}$ Furthermore, the International Law Association has been actively engaging in international lawmaking and codification for more than a century. ${ }^{14}$ The Paris Peace Conference of 1919 is considered one of the early milestones for NGOs' participation in

8 Martha Finnemore and Kathryn Sikkink, "International Norm Dynamics and Political Change" 52(4) International Organization (1998).

$9 \quad$ Finnemore and Sikkink, supra note 8, p. 897.

10 See Cecilia Albin, "Can NGOs Enhance the Effectiveness of International Negotiation?", 4(3) International Negotiation (1999) p. 3.

11 I refrain from a substantive connotation of NGOs because of the highly subjective undertaking to judge whether or not NGOs pursue substantially commendable values.

12 For the subsequent brief historical overview I primarily rely on the studies of Charnovitz and Paul.

13 Steve Charnovitz, "Two Centuries of Participation: NGOs and International Governance" 18(2) Michigan Journal of International Law (1997) p. 194, referring to James Wilford Garner, Recent developments in international law (1925) pp. 655-656; Jackson Harvey Ralston, International Arbitration from Athens to Locarno (1929) p. 139.

14 The International Law Association encouraged for example states to develop private international law on shipping. Charnovitz, supra note 13, p. 194 referring to International 
international law-making. ${ }^{15} \mathrm{NGOS}$, such as the Woman's International League for Peace and Freedom initiated parallel conferences themselves and succeeded in handing over copies of their resolutions to the official peace delegates. ${ }^{16}$

During the decade of 1935-1944, international cooperation increased but the call for NGO input diminished. ${ }^{17}$ An explanation for this shift can be found in the fact that the officials of international organisations themselves had gained more experience and expertise that created a certain independence of NGOs. However, the successor to the League of Nations, the United Nations, refocused on NGOS. ${ }^{18}$ Due to the increasing codification efforts of states, NGOs received more opportunities to weigh in on issues. ${ }^{19}$ During the period $1950-$ 1971, NGO activity at the UN truly started to flourish. The General Assembly of the United Nations convened the International Law Commission to encourage the progressive development and codification of international law. ${ }^{20}$ The merits of NGOS were recognised primarily in the efforts to codify human rights law and environmental law. ${ }^{21}$ The involvement of NGOs became formalised by

Law Association, "Report of the Twenty-second Conference" (1906) pp. vii-xiv (summarising impact).

15 Charnovitz, supra note 13, p. 213, referring to Warren F. Kuehl, Seeking World Order. The United States and International Organisations to 1920 (1969) p. 267.

16 Charnovitz, supra note 13, p. 214.

17 An example is the International Radio Conference in Cairo, 1938, during which only a few NGOS were allowed to participate. Charnovitz, supra note 13, p. 246.

18 James A. Paul, "Civil Society and the United Nations", in H. Moksnes and M. Melin (eds.), Global Civil Society: Shifting Powers in a Shifting World (2012) pp. 64-82.

19 The codification of the Law of the Sea in the Convention on the Law of the Sea, Dec. 10, 1982, U.N.T.S. no. 31363, gives a strong example of the increasing opportunities for NGOS to influence the lawmaking process. See Karl Raustiala, "NGOs in International TreatyMaking" in D. B. Hollis (ed.), The Oxford Guide to Treaties (2012) p. 153.

20 Charter of the United Nations, Oct. 24, 1945, 1 U.N.T.S. XVI, under Article 13, paragraph 1. As a means for the discharge of these responsibilities, the General Assembly, in 1947, established the International Law Commission. See United Nations, "The Work of the International Law Commission", 6th ed. vol. 1 (2004); Gentian Zyberi, "Non-state actors from the perspective of the International Law Commission" in J. D'Aspremont (ed.), Participants in the International Legal System, Multiple perspectives on non-state actors in international law (2011) pp. 165-178.

21 See for studies on the involvement of NGOs in human rights issues: Peter Willetts, The Conscience of the World:The Influence of Non-Governmental Organisations in the UNSystem (1996); Renera Gertrudis Sybesma-Knol, The Status of Observers in the United Nations (1981) p. 309; Marlies Glasius, "Pipe dream or panacea? Global civil society and economic and social human rights” in M. Kaldor, M. Albrow, H. Anheier, and M. Glasius (eds.), Global Civil Society 2006/7 (2007); Claude E. Welch jr., NGO's and Human Rights, Promise 
an accreditation system introduced in 1950. Under Article 71 of the UN Charter, NGOs can apply for accreditation with the Economic and Social Council (ECOSOC) of the United Nations. ${ }^{22}$

In the early 1970s NGOs presence intensified in terms of size and diversity, partly under the umbrella of the Conference of NGOs in Consultative Relationship with the United Nations. ${ }^{23}$ The UN Department of Public Information began to accredit nationally based NGOS, enabling the presence of more and different voices, including those from the global south. ${ }^{24}$ The UN Conference on the Human Environment, held in Stockholm in 1972, is often cited as a milestone in the history of NGO participation in international lawmaking. ${ }^{25}$ From that moment on, NGOS were expressly appreciated as appropriate contributors to global governance, even as 'integral to the United Nations.' ${ }^{26}$ The General Assembly included NGOs in the work of its committees, ${ }^{27}$ and

and Performance (2001); Pierre-Marie Dupuy and Louisa Vierucci, NGOs in International Law: Efficiency in Flexibility? (2008); See for further reading on NGOs contributions to environmental law: Abram Chayes and Antonia Handler Chayes, The New Sovereignty: Compliance with International Regulatory Agreements (1995) pp. 250-70; A. Dan Tarlock, "The Role of Non-governmental Organizations in the Development of International Environmental Law", 68(1) Chicago-Kent Law Review (1992); Chadwich Alger, "Emerging Roles of the NGO in the UN system: From Article 71 to a People's Millennium Assembly" 8(1) Global Governance (2002); Michael Bowman, "International Treaties and the Global Protection of Birds. Part II" 11(1) Journal of International Environmental law (1999) p. 298.

22 See Charter of the United Nations, Oct. 24, 1945, 1 U.N.T.S. XVI, art 71.

23 Paul, supra note 18, p. 64.

24 General Assembly Resolution 13 (I) established the DPI in 1946 UNGA to promote global awareness and understanding of the work of the United Nations. Resolution 13/(I), A/RES/13(I), Feb. 1, 1946 (Organisation of the Secretariat).

25 Anne Thompson Feraru, "Transnational Political Interests and the Global Environment" 28(1) International Organization (1974) p. 41. See also Steven Bernstein, "Legitimacy in Global Environmental Governance" 1(1-2) Journal of International Law \& International Relations (2004). See generally on the history, context and impact of the Stockholm conference, Nico Schrijver, Development without Destruction. The UN and Global Resource Management (2010) pp. 48-59.

26 Riva Krut, "Globalization and Civil Society: NGO Influence in International DecisionMaking”, United Nations Research Institute for Social Development, Discussion Paper No. 83 (1997) p. 11; Boutros Boutros-Ghali, "Speech to the DPI Annual Conference" (1995).

27 Willetts, supra note 21, p. 196, referring to UNGA, Resolution 104 (S-I), A/RES/104(S-I), May 5, 1947 (Hearing for the Jewish Agency for Palestine), and UNGA, Resolution 105 (S-I), A/RES/105(S-I), May 7, 1947 (Hearing for the Arab Higher Committee), provided for 'the First Committee to grant a hearing' to the Jewish Agency for Palestine and the Arab Higher Committee, respectively. Ecosoc, Resolution 288B (X), 27 February 1950, par. 4o(f); ECOSOC, Resolution 1296 (XLIV), E/RES/1968/1296, May 23, 1968 (Arrangements for 
adopted a practice of organising 'interactive hearings' with civil society organisations before major $\mathrm{UN}$ events. ${ }^{28}$

NGOs' presence has been particularly evident in the specialised conferences, which increased in scope and number during the early 199os. Examples are the UN Conference on Environment and Development in Rio de Janeiro in 1992 and the Fifth World Conference on Women in Beijing in 1995. In the last three decades the number of civil society organisations engaged in international law-making has increased at an unprecedented pace. ${ }^{29}$

However, sympathy for NGO participation in international law-making seems to have weakened in recent decades. This could be partly explained by the increased attempts of international organisations to attract corporate actors, characterising a new paradigm called the 'multi-stakeholder dialogue'. These corporate actors often have, due to their size and the impact of their decisions on society, a better bargaining position than many NGOs. ${ }^{30}$ Besides, particularly after the attacks of September 11, 2001 and the consequential increased tensions in world politics, states are less tolerant of civil society actors and seek to retain their tight grip on UN law-making processes. ${ }^{31}$

\section{The NGo Democratic Legitimacy Thesis}

Notwithstanding the ups and downs in intensity of, and attitude towards NGO involvement in international law-making, the thesis that their involvement contributes to the democratic legitimacy of international law has been defended for over a century. ${ }^{32}$ Strong claims have been advanced that the participation

Consultation with Non-Governmental Organizations), par. 46(f); and Ecosoc, Resolution 1996/31, E/RES/1996/31, July 25, 1996 (Consultative relationship between the United Nations and non-governmental organizations), par. $67(\mathrm{f})$.

28 International Law Association, Committee on Non State Actors, "Second Report of the Committee: Non state Actors in International Law: Law Making and Participation Rights" Sofia Conference (2012) p. 12.

29 See Yearbook of International Organisations 2014, <http://www.uia.be/yearbookinternational-organisations-online $>$ (accessed June 2017) 33, fig. 2.9.

30 Paul, supra note 18 , pp. $74-75$.

31 See Jude Howell, Armine Ishkanian, Ebenezer Obadare, Hakan Seckinelgin and Marlies Glasius, "The Backlash against Civil Society in the Wake of the Long War on Terror", 18(1) Development in Practice (2008); Paul, supra note 18, p. 77.

32 See Steve Charnovitz, "Nongovernmental Organizations and International Law", 100(2) American Journal of International Law (2006) pp. 349-366, referring to Simeon Baldwin, "The International Congresses and Conferences of the Last Century as Forces Working 
of NGOS, often captured in the broad term of 'civil society', is essential for a democratically legitimate international order. ${ }^{33}$ NGOs allegedly advance the possibilities of participation and control in global governance through pushing for more transparency, policy monitoring, and review, and promotion of formal accountability mechanisms. ${ }^{34}$ Scholars present NGOs as representatives of marginalised people. ${ }^{35}$ In this view, states are considered to be imperfect representatives of public opinion as they disregard minority viewpoints. The participation of NGOS allegedly meets the shortcomings of states by giving a platform to otherwise neglected voices. ${ }^{36} \mathrm{NGOS}$ are considered especially sensitive to these outcast voices. They can help people to assert their won power and make efforts to listen to those who are never or rarely heard, rather than seeking governmental or economic power. ${ }^{37} \mathrm{NGOS}$ are also often understood

Toward the Solidarity of the World", 1 American Journal of International Law (1907) pp. 565, 576; Georges Scelle, Une Crise De La Société Des Nations, La Reforme Du Conseil et L'Entrée de l'Allemagne A Genève (1927) pp. 144-46; Walter Schücking, "Le développement du Pacte de la Société des Nations", Recueil Des Cours 20, (1927) pp. 349, 394; Alexandre Berenstein, Les Organisations Ouvrières: Leurs Compétences Et Leur Role Dans La Société Des Nations (1936) p. 277; David Mitrany, “An Advance in Democratic Representation”, 6 International Associations (1954) pp. 136, 188.

33 See Roland Pierik and Geoffrey Gordon, "Liberal Political Philosophy: The Role of NonState Actors and Considerations of Global Justice", in B. Reinalda (ed.), The Ashgate Research Companion to Non-State Actors (2011) p. 5. And see Steve Charnovitz, "The Illegitimacy of preventing NGO participation", 36(3), Brooklyn Journal of International Law (2011) pp. 899-90o, referring to Nathan Feinberg, "La Pétition en Droit International", 40 Recueil des Cours (1932) p. 631 (Charnovitz's translation); Joseph Kunz, "Book review”, $5^{2}$ American Journal of International Law (1958), reviewing Karl Zemanek, Das Vertragsrecht der Internationalen Organisationen (1957).

34 Jan Aart Scholte, "Civil Society and Democratically Accountable Global Governance", 39(2) Government and Opposition (2004) pp. 217-222.

35 Especially in the human rights field NGOs are seen as the new representatives of the people. The idea of NGOS as serving a representative function at the United Nations goes back to how UN member governments implemented Article 71 in 1950 in calling for an accredited NGO to "represent a substantial proportion of the organized persons within the particular field in which it operates".

36 Iris Marion Young, Inclusion and Democracy (2000) p. 67.

37 Marc Nerfin, "Neither Prince nor Merchant: Citizen - An Introduction to the Third System", in S. J. Patel, K. Ahooja- Patel, A. Gordon Drabek, M. Nerfin (eds.), World Economy in Transition, Essays Presented to Surendra Patel on His Sixtieth Birthday (1986); Victor Bekkers and Arthur Edwards, "Legitimacy and Democracy", in V. Bekker, G. Dijkstra, A. Edwards, M. Fenger (eds.), Governance and the Democratic Deficit. Assessing the Democratic Legitimacy of Governance Practices (2007) p. 51; Robert Dahl, A Preface to Democratic Theory (1956). 
as facilitators of a flourishing global public sphere, ${ }^{38}$ and as contributors to the strengthening of deliberations taking place during international law-making processes. ${ }^{39}$ The NGO democratic legitimacy thesis is generally accompanied by a call for institutional innovations to connect governments, international organisations, civil society, and corporate actors, ${ }^{40}$ which have been endorsed by many international organisations. ${ }^{41}$

It is noteworthy that around the turn of the twentieth century, an increase in critical scholarly work can be witnessed. Scholars, including but not limited to Anderson and Johns, have contested specifically the claimed correlation between the participation of NGOs in international law-making and democratic legitimacy of international law. ${ }^{42}$ Democratic expectations regarding NGOS are considered naïve and optimistic. ${ }^{43}$ These critical notes might represent something of an adverse reaction towards the scholarly fascination with the 'innate goodness' of NG Os. ${ }^{44}$ Critics doubt both motives and actions of NG Os. ${ }^{45}$ Some

38 Christoph Görg and Joachim Hirsch, "Is International Democracy Possible?", 5(4) Review of International Political Economy (1998) p. 599.

39 (1) Daniel Esty, "Non-Governmental Organizations at the World Trade Organisation: Cooperation, Competition, or Exclusion", 1 Journal of International Economic Law (1998) p. 135; Alfred Pfaller and Marika Lerch, Challenges of Globalization: New Trends in International Politics and Society (2005) p. 109.

40 See Jan Martin Witte, Wolfgang Reinicke and Thorsten Benner, Beyond Multilateralism: Global Public Policy Networks (2000).

41 One of the most explicit endorsements of this claim was made at the 2005 World Summit. See for a brief summary "2005 World Summit: An overview" < www.un.org/ga/documents/ overview2005summit.pdf> (accessed January 2018). See also Secretary-General of the United Nations, Report: "In larger freedom: towards development, security and human rights for all", A/59/2005/Add.3 (2005); Commission on Global Governance, Our Global Neighbourhood: The Report of the Commission on Global Governance (1995) p. 254.

Kenneth Anderson, "Review: What NGO Accountability Means - and Does Not Mean", 103(1) American Journal of International Law (2009); Kenneth Anderson, “'Accountability' as 'Legitimacy': Global governance, Global Civil Society and the United Nations", 36(3) Brooklyn Journal of International Law (2011); Gary Johns, "The NGO Challenge: Whose Democracy is it Anyway?", A workshop sponsored by the American Institute, June vol. 11 (2003).

43 Oren Perez, "Normative Creativity and Global Legal Pluralism: Reflections on the Democratic Critique of Transnational Law", 10(2) Indiana Journal of Global Legal Studies (2003) p. 42.

44 Crawford Young, "In Search of Civil Society", in J. W. Harbeson, D. Rothchild, and N. Chazan (eds.), Civil Society and the State in Africa (1994) p. 47. See also Julie Mertus, "Doing Democracy 'Differently': The Transformative Potential of Human Rights NGOs in Transnational Civil Society", Third World Legal Studies vol. 15, article 8 (1998-1999) pp. 205-236. Gary Johns, "Conspiracies and NGOs" Review 55(3) Institute of Public Affairs Review (2003) p. 29. 
argue that the information spread by NGOs distorts, rather than enlightens, public opinion. ${ }^{46}$ Others claim that the large number of NGOs active in the international legal order creates an 'excess of civil society'. ${ }^{47}$ The competition with each other for access to resources and means to influence international law-making distracts most NGOs from their social purpose. ${ }^{48}$ NGOs are assumed to have an inherently biased position, and the risk of NGOs forming dominant factions is considered to increase with their participation in international law-making forums.

The increasing participation of NGOs in international law-making, that was most unprecedented around 2000 and recently plateaued, ${ }^{49}$ has fuelled scholarly debate not only about their contribution to the democratic status of international law-making, but also about the democratic legitimacy of NGOs themselves. ${ }^{50}$ Critics argue that NGOS are unrepresentative and unaccountable. ${ }^{51}$ The detachment between NGos and the people they purport to represent is considered to reinforce a global divide of wealth, mobility,

46 Peter Simmons, "Learning to Live with NGOs", 112 Foreign Policy (1998) pp. 82-96.

47 Hildy Teegen, Jonathan Doh and Sushil Vachani, "The importance of nongovernmental organisations (NGOs) in global governance and value creation: An international business research agenda", 35(6) Journal of International Business Studies (2004) p. 472, referring to Ann Florini, The coming democracy: new rules for running a new world (2003) p. 39.

48 Thomas Dichter, "Globalization and Its Effects on NGOs: Efflorescence or a Blurring of Roles and Relevance?”, 28(4) Non profit and Voluntary Sector Quarterly (1999) pp. 38-58.

49 Helmut Anheier, Marlies Glasius, and Mary Kaldor, "The Global Civil Society Yearbook: Lessons and Insights 2001-2011", in M. Kaldor, H. L. Moore, S. Selchow, Global Civil Society. Ten Years of Critical Reflection (2012) p. 19.

$5^{0}$ See Steven Wheatley, "A Democratic Account of the Right to Rule in Global Governance", 18(2) Swiss Political Science Review (2012) pp. 161-162.

$5^{1}$ Scholars predominantly argue that civil societies and NGOs are often fragmented, unorganised, uncooperative, and weak. See Claire Mercer, "NGOs, Civil Society and Democratization, A Critical Review of the Literature", 2(1) Progress in Development Studies (2002) p. 13; Holly Cullen and Karen Morrow, "International Civil Society in International Law: The Growth of NGO Participation", 1(1) Non-State Actors and International Law (2001) p. 10; Gabriella Blum, "Bilateralism, Multilateralism, and the Architecture of International Law” 49(2) Harvard International Law Journal (2008) p. 364; See Balakrishnan Rajagopal, "Completing a full circle: democracy and the discontent of development", in B. Rajagopal (ed.), International Law from Below: Development, Social Movements and Third World Resistance (2003); Makau Mutua, "Savages, Victimes and Saviors: The Metaphor of Human Rights", 42(1) Harvard International Law Journal (2001) pp. 204-205; Paul Wapner, "Defending Accountability in NGOs" 3(1) Chicago Journal of International Law (2002) p. 156 . 
information, and access to audience. ${ }^{52}$ Slim summarises the debate in one thorny question: "[d]o NGOs speak as the poor, with the poor, for the poor or about the poor?"53

The academic discourse on the NGO democratic legitimacy thesis demonstrates an interesting dynamic. On one hand, NGOs are considered ideologically committed to participation, political equality and freedom as a strategy for emancipation and empowerment and therefore apt to contribute to the democratic legitimacy of international law. On the other hand, both proponents of the thesis and its critics see this contribution as only operational when NGOs are democratically organised. The focus of the debate shifts back and forth from the question whether NGOs can be used as a cure for the current undemocratic domination by international law to the possible domination exercised by NGOs themselves.

Apparently NGOs' limited representativeness, ${ }^{54}$ their elitist character, ${ }^{55}$ their lack of accountability, and the dependency of NGOs on states are assumed to preclude the NGO democratic legitimacy thesis. ${ }^{56}$ The argument is based on a certain urge for reciprocity. ${ }^{57}$ Anheier's statement is exemplary: "[I]f a nonprofit seeks to promote democracy and the rule of law, must it not itself be democratically organized and soundly governed?"58 Also, Black's reasoning

52 David W. Kennedy, “The International Human Rights Movement: Part of the Problem?” 15 Harvard Human Rights Journal (2002) p. 121.

53 Hugo Slim, "By What Authority? The Legitimacy and Accountability of Non-governmental Organisations", Paper for The International Council on Human Rights Policy International Meeting on Global Trends and Human Rights - Before and after September 11, (2002).

54 See Cullen and Morrow, supra note 51; Johns, supra note 42.

55 See Kenneth Anderson, "The Ottawa Convention Banning Landmines, the Role of International Non-governmental Organisations and the Idea of International Civil Society", 11(1) European Journal for International Law (2000) p. 117.

56 See Anton Vedder (ed.), NGO Involvement in International Governance and Policy. Sources of Legitimacy (2007).

57 A recent example of the tendency to prioritise NGOs democratic legitimacy is the article of Marxsen. Christian Marxsen, "The Promise of Global Democracy. The International Impact of Global Civil Society", 47(4) New York University Journal of International Law and Politics (2015).

58 Helmut Anheier, "What Kind of Nonprofit Sector, What kind of Society?: Comparative Policy Reflections", 52(7) American Behavioral Scientist (2009) p. 1090. 
characterises the NGO democratic legitimacy debate: "Enrolment can potentially enhance a regulator's legitimacy within a legitimacy community, but if the actor enrolled is not considered legitimate, it may well erode it".59

A democratic ideal-type of NGOs is constructed. ${ }^{60}$ NGOs should prove that they are authentic intermediaries of the interests of the 'people.61 Their democratic deficits affect the authority of international law as they lead to the degradation of the democratic processes to the detriment of the people truly affected by global legal developments. ${ }^{62}$ Equally resilient in academic discussions is the argument that NGOS only have democratic effect as long as they are capable of remaining independent of state organs. ${ }^{63}$ Further, in more general terms, scholars require civil society at large to be a transparent sphere in order to be able to create space for consultation, evaluation, and revision by interested and affected people. ${ }^{64}$

At first sight it seems perfectly valid to put requirements by law or by other rules on the organisation of NGOS in order to prevent that NGOS obstruct instead of contribute to democratisation. ${ }^{65}$ Evidently there could be tensions

59 Julia Black, "Constructing and Contesting Legitimacy and Accountability in Polycentric Regulatory Regimes", 2(2) Regulation \& Governance (2008) p. 148.

6o Exemplary is the summary of Wheatley in which he dismisses the validity of the NGO democratic legitimacy thesis. Wheatley, supra note 50, p. 161.

61 Anderson, supra note 55, p. 117. As a reaction to that criticism, standardisation on independent institutional footing or accountability of NGOs has been developed. The content of the internal requirements depends on what specific role in democratic legitimising international law is prescribed. See for different requirements: Görg and Hirsch, supra note 38, p. 6o2; Allen Buchanan, Justice, Legitimacy and Self-Determination. Moral Foundations for International Law (2004) p. 317; Joachim Hirsch, "The States New Clothes: NGOs and the Internationalization of States", 15(2) Rethinking Marxism (2003) p. 257.

62 Michael Edwards, NGO Rights and Responsibilities: A New Deal for Global Governance (2000) p. 2.

63 An interesting question in this regard is whether a tension arises between the endogenous precondition to remain independent and the requirements to internally democratise. The latter looses congruence with the former of course when it is not the NGO itself that chooses to democratise, but when peers, states or international organisations put the NGO under pressure to reform. One can question in the latter case whether that is not contrary with the NGO's autonomy and self-identity.

64 Jan Aart Scholte, "Conclusion", in J. A. Scholte (ed.), Building Global Democracy? Civil Society and Accountable Global Governance (2011) p. 333.

65 Ernst Hirsch Ballin, "Werking en verwerking van grondrechten", in L. Heyde, J. Leijten, Th. Mertens, B.P. Vermeulen (eds.), Begrensde Vrijheid. Opstellen over mensenrechten aangeboden aan Prof. Dr D.F. Scheltens bij zijn afscheid als hoogleraar aan de Katholieke Universiteit Nijmegen (1989) p. 137, referring to Ernst Hirsch Ballin, "Subsidiëring van het 
between the power and impact that NGOs have and the accountability mechanisms at place. ${ }^{66}$ Notwithstanding the intuitive inclination to impose requirements such as transparency, accountability, and representation on NGOs, the appropriateness of imposing democratic norms on NGOs should be critically assessed.

\section{$5 \quad$ The Problem of the Ungeneralisability of NGOs}

Underlying the imposition of democratic norms on NGOS, there is a tendency to generalise 'the NGO' as an actor, capable of taking up a pre-determined role in democratic legitimacy theory. ${ }^{67}$ Understanding NGOs to be democratic legitimisers presupposes that a uniform image of NGOs ought to, and implicitly can, be determined in international legal theory as comparable but distinct from 'states' or 'international organisations' ${ }^{68}$

A large number of studies have empirically examined the activities of global civil society, thereby assuming a broad and shared understanding of what a global civil society or an NGO entails. ${ }^{69}$ Lists have been developed based on

identeitisgebonden particulier initiatief in een pluriforme samenleving: confrontatie met de eisen van een democratische samenleving", 13(17) Tijdschrift voor Openbaar Bestuur (1987) pp. 351-355.

66 Charnovitz, supra note 5, p. 14.

67 See for example Macdonald's statement, "[b]ut irrespective of the extent of the organizational transformations required, focusing on NGOS in their current form as a starting point for theoretical analysis can help identify novel pathways to global democratization, which involve treating non-state actors quite differently from how traditional state-based democratic models have treated them". Terry Macdonald, Global Stakeholder Democracy: Power and Representation Beyond Liberal States (2008) p. 17. Comparable is the scholarly assumption that 'young people' embody an inherently progressive revolutionary potential making them the natural enemies of autocrats. See for a critical note Christian Caryl, "The Young and the Restless", Foreign Policy (2014). Only some sceptics have disapproved the abstract attitude towards NGO involvement, stating that it is misleading to regard all intervention in international law-making by non-state actors as moving in the same direction. See for example, Alan Boyle and Christine Chinkin, The Making of International Law (2007) p. 60.

68 Critics have continuously questioned the possibility to uphold the theoretical division between state, NGOs and private profit seeking organisations. See Stephen Hopgood, "Reading the Small Print in Global Civil Society: The Inexorable Hegemony of the Liberal Self", 29(1) Millennium:Journal of International Studies (2000) pp. 1-25.

69 Barbara Woodward, Global Civil Society in International Law-making and Global Governance. Theory and Practice (2010) p. 73 . 
the typologies ${ }^{70}$ or taxonomies ${ }^{71}$ of NGOS. The characterisations of NGOS vary according to the writer ${ }^{72}$ as well as the definitions held ${ }^{73}$ and the selection of NGOS as the subjects of their research. However, the existing diversity of organisations that are covered by the notion ' $\mathrm{NGO}$ ' is not perceived to be an obstruction to a general discussion of their pre-determined merits for international law-making. ${ }^{74} \mathrm{NGO}$, under such a general account, are assumed to be able to have a standard form and offer an organised will. ${ }^{75}$ However, the same generality in expectations continues to change in terms of content according to the different normative perspectives of the respective scholar. ${ }^{76}$

The inclination to base conclusions on generalisations, with presumably strong predictive power, gives insight into one of the recurring tendencies in the NGO democratic legitimacy thesis: the assumption of structural systematics in global civil society. Scholars engaged in the debate imply that the sum of all NGOS, although different from one another, can be defined as a coherent, bound, identifiable object of theory. One can question the persuasiveness of

70 Debora Spar and James Dail, "Of Measurement and Mission: Accounting for Performance in Non-Governmental Organizations", 3(1) Chicago Journal of International Law (2002) p. 171.

71 See Simmons, supra note 46.

72 Characterisations of NGOs are reinvented from 'representatives', the 'voice', 'mobilisers', to the 'conscience of the world'. See Willetts, supra note 21. Labelling changed in time, from 'new social movements', to part of the 'new policy agenda'. See Mary Kaldor, "The Idea of Global Civil Society”, 79(3) International Affairs (2003) pp. 584-586.

73 There is a diversity in defining NGOs, among others of Daphné Josselin and William Wallace, "Non-State Actors in World Politics: A Framework" in D. Josselin and W. Wallace (eds.), Non-State Actors in World Politics (2001) pp. 3-4; Hirsch, supra note 61, p. 239.

74 Most scholars and international agencies speak in general terms about the merits of NGOs. The World Bank states for example: "NGOs and civic movements are on the rise, assuming an ever-larger role in articulating people's aspirations and pressuring governments to respond". World Bank, World development report 1999/2000: entering the 21st century (2000) p. 43. Another typical way of framing the contribution of NGOs: "The emergence of global civil society holds the promise of making existing international institutions more democratic, transforming them through innovation and experimentation, and anchoring them in world opinion." Maxwell Cameron, Brian Tomlin and Robert Lawson, To Walk without Fear: The Global Movement to Ban Landmines (1998) p. 13.

75 Frederick Barnard, Democratic Legitimacy, Plural Values and Political Power (2001), p. 149, referring to George Cole, "Conflicting social obligations", 15 Proceedings of the Aristotelian Society (1915) p. 158.

76 See Louise Amoore and Paul Langly, "Ambiguities of Global Civil Society", 30(1) Review of International Studies (2004) pp. 89-110. 
considering NGOs as an object of a law-like generalisation, given their formlessness and variety of manifestations. ${ }^{77}$

Three preliminary remarks can be made in this respect. First, it is clear that NGOs differ from one another. ${ }^{78}$ This observation is in line with the most common criticism on any attempt to define the NGO. Although there is a certain level of consensus regarding the importance of associations for democratic political processes as well as the virtuous role that the participation of citizens might play or have played in democracies, the same consensus hides a significant disagreement over how to understand and select specific actors who are part of the broad term 'associations'. The term NGO can be used quite freely to label any association of people, which may be operational, providing services, advocacy oriented, or protesting. NGOs might be large, small, rich, representing the voice of liberal or left wing activists. ${ }^{79}$ NGOs might be organised to attain goals beneficial to the self, such as football clubs or chambers of commerce, or to strive for aims that are altruistic, such as the World Wildlife Fund or Amnesty International. 80

Different NGOs have different levels of independence. The donor structure of an NGO might be made up of private companies, states, a few well-to-do individuals, or a large group of disadvantaged people..$^{81}$ In addition to the clear-cut financial support of members, most NGOS maintain donor relationships with philanthropic foundations, private companies, or governments. The financial dependence of NGOS on many actors with divergent institutional settings obfuscates thinking in general terms about how, to whom, and on the basis of which standards NGOs should be held accountable.

77 My argument is in line with what Skocpol has argued in her study of the history of civil society in the United States. Skocpol has criticised the systemic approach of, among others, civil society theorist Putnam. See Theda Skocpol, Diminished Democracy. From Membership to Management in American Civic Life (2003).

78 In order to give analytical guidance for international organisations to clarify for what purpose civil society engagement is needed Pedraza-Fariña offers a helpful taxonomy. See Laura Pedraza-Fariña, "Conceptions of Civil Society in International Law-making and Implementation: A Theoretical Framework", 34(3) Michigan Journal of International Law (2013) pp. 655-656.

79 Krut, supra note 26, p. 14; Simmons, supra note 46.

8o Michael Yaziji and Jonathan Doh, NGOs and Corporations: Conflict and Collaboration (2009) p. 5 .

81 See on the relationship between funding sources and NGO activities: Michael Edwards and David Hulme, "Too Close for Comfort? The Impact of Official Aid on Nongovernmental Organizations, 24(6) World Development (1996). See Simmons, supra note 46, for a few illustrative examples of the enormous differences between NGOs. 
Notwithstanding the obvious variety of groups that are referred to by the term NGO, it is not so much the empirical fact of diversity that I consider problematic for their generalised contribution to the democratic legitimacy of international law. The fact that NGOs can easily change internally in terms of constituency, purpose, activity, and donor construction is more puzzling. This brings me to my second hesitation with regard to the common generalisations of form and functioning of NGOS. When one mentions NGOS, one refers to a body of organisations with a prismatic variety of content. ${ }^{82}$ Their manifestations - their position taken towards other actors and roles in a society - are subject to unpredictable change. The argumentative power of the generalisations concerning NGOS is flawed by NGOs' indeterminacy, partly by the fact that 'NGO' might mean anything, but more importantly, that tomorrow's NGOs might be complete different entities than they are today. ${ }^{83}$

One can envisage that an expectation concerning the representativeness of an NGO that was primarily based on individual donors as part of a marginalised group does not hold when the same NGO is flourishing five years later on the basis of a substantial gift from one individual donor. The way an NGO works might change according to context, which is sometimes aimed at cooperation with states and international organisations, ${ }^{84}$ and sometimes in opposition, and sometimes on their own initiative, mobilising the 'excluded' in order to give voice to topics that are otherwise neglected. Because of the fact that an NGO originates from a private initiative, there are no guarantees concerning

82 This fact complicates the analysis of the impact of NGOs at local, national, and global levels. This complication is also acknowledged by: Thomas Carroll, Intermediary NGOs: The Supporting Link in Grassroots Development (1992); Julie Fisher, The Road from Rio: Sustainable Development and the Nongovernmental Movement in the Third World (1993); Alan Fowler and Rick James, "The Role of Southern NGOs in Development Cooperation: A Review", 1(2) Occasional Paper Series (1994).

83 See for the possible effects of general associations of NGOs: Islah Jad, "NGOs: Between Buzzwords and Social Movements", 17(4/5) Development in Practice (2007) pp. 622-629. This adherence to generality presumably strengthens the credibility of the positions taken. David Kennedy, "When Renewal Repeats: Thinking Against the Box", 32 New York University Journal of International Law and Politics (2000) p. 373; Martti Koskenniemi, From Apology to Utopia. The Structure of International Legal Argument. Reissue with a new Epilogue (2006) p. 589 .

84 For example, Pedraza-Fariña points out that a new governance conception of civil society understating strategies of collaboration and that views civil society as 'partners' of both government and business are often implicit but characteristic for the institutional design of U. N. General Assembly Declaration of Commitment on HIV/AIDS (UNGASs). Laura Pedraza-Fariña, supra note 78, p. 654 . 
the consistency of its policy, financial structure, or even its existence. This is not a bad thing per se, but it is problematic for the validity of the ante hoc normative expectations that underlie the NGO democratic legitimacy thesis.

Interrelated to the contentiousness of determining the role of NGOs in international law-making is the question of whether NGOS can be generalised as an equivalent for, or part of, (global) civil society is correct, ${ }^{85}$ which takes us to my third hesitation. The collection of NGOS, often equated with civil society, is far from a constant and uncontested factor. Many biases are hidden behind the assumingly 'neutral' connection between NGOs and global civil society. The analytical terms used in current writings on NGO involvement are permeated by a distinction between public and private actors, in which public is state and private is non-state. For example, from a linguistic (and consequently political) point of view, placing the NGO within civil society prevents thinking of NGOs as participants in the exercise of public authority. 86

There are three manifestations of the controversy surrounding global civil society and NGOs. First, the actual existence of an international public or civil society is highly contentious. Second, there is debate concerning the alleged benefits that a global civil society might bring to the democratic legitimacy of international politics. Third, there is no agreement over the boundaries of the concept: whether the generally shared ideal or typical representation of global civil society can be perceived as an identifiable sphere, space, or 'third system'. ${ }^{87}$

The reason for disagreement concerning the understanding of civil society is that concepts such as civil society and NGOs are, less than complex in terms of definition, inherently fluid and dynamic. The fragmentation in terms of what is implied by the term NGO excludes a priori conclusions with regard to the NGO democratic legitimacy thesis. ${ }^{88}$ Upholding a thesis based on whatever contribution of NGO to international law requires empirical studies to learn case by case what role is performed by which organisation, and in

85 Also Amoore and Langly detect and criticise "the tendency to equate GSC (red: Global Civil Society) with the practices of voluntary associations". "In short GCS becomes defined as voluntary associations and vice versa." Amoore and Langly, supra note 76, p. 94.

86 Macdonald, supra note 67 , pp. $44-45$. The distinction between public and private is formally acknowledged, as states have, contrary to NGOS, international legal personality, states have a vote, unrestricted access, and therefore actual political power.

87 Amoore and Langly, supra note 76, p. 92, referring to Richard Falk, "Global Civil Society: Perspectives, Initiatives, Movements", 26(1) Oxford Development Studies (1998) p. 100.

88 MacIntyre argues that the studies of human behaviour cannot offer any general law-like observation, although they often assume to do exactly that. Alasdair MacIntyre, After Virtue (2011) pp. 93-102. 
what political setting. ${ }^{89}$ Empirical studies should refer to intentions, purposes, and reasons for actions of NGOs engaged in international law-making, to "purify [the] descriptive vocabulary" of the current NGO democratic legitimacy debate. ${ }^{90}$ The fulfilment of the pre-determined responsibility, which is assumed with the NGO democratic legitimacy thesis, can be empirically tested ex post, or ad hoc. However, notwithstanding its explanatory power, ${ }^{91}$ even a generalisation based on empirical studies still lacks predictive power. ${ }^{92}$ In sum, the diffuse and ever-changing characteristics of NGOs in terms of structure, content, organisation, and membership exclude any ante hoc conceptual expectation. ${ }^{93}$

Besides the questionable success of formulating general normative expectations with regard to NGOs, it is dubious if one should subject NGOS, which are primarily content-driven, to content-independent democratic norms. In the subsequent sections, I will first discuss the general problem of governing NGOS, ${ }^{94}$ and second, I question the merits of describing $\mathrm{NGO}$ involvement in content-independent terms.

89 However, case studies are complicated by the fact that the efforts of NGOs to change the law often spread out over more than two decades. Only at a reflexive moment after a culmination of interactions initiated and driven by NGOs, one might be able to indicate that NGOs did have actual impact on the law.

$90 \quad$ MacIntyre, supra note 88, p. 98.

91 According to Macintyre, studying NG Os role empirically will not do the trick. Predictability in human affairs is systematically obstructed. MacIntyre, supra note 88, p. 98; p. 106, pp. 109-114.

92 MacIntyre, supra note 88, chapter 7 and 8.

93 Charnovitz, warns us that the lack of common structures, roles of NGOs and levels of involvement complicates thinking about suitable governmental structures. Charnovitz, supra note 5, p. 32. See also Taco Brandsen, Wim van de Donk and Kim Putters, "Griffins or Chameleons? Hybridity as a Permanent and Inevitable Characteristic of the Third Sector", 28 International Journal of Public Administration (2005) p. 750; Peter Frumkin, On Being Nonprofit. A Conceptual and Policy Primer (2002) p. 1; Nancy Rosenblum, Membership and Morals, The Personal Uses of Pluralism in America (1998) p. 155.

94 I borrow the title from the Brooklyn Journal of International law, the Chicago Journal of International Law, and Chicago Kent Law School Symposium, "Governing Civil Society: NGO Accountability, Legitimacy and Influence”, 36 Brooklyn Journal of International Law (2011) pp. 813-1074. 
The reasons for including NGOS in international organisations are manifold. The most obvious one is that the working area of NGOs and governmental actors often overlap. The values on which NGOs base their activities and their existence is often related to governmental activities, which makes it mutually beneficial for NGOs and governmental actors to work together. Interestingly, not only scholars prescribe an internal democratisation of NGOs before their contribution to international law can be considered justifiable, but also some legal documents concerning the accreditation of NGO participation in international organisations consider it a prerequisite for their involvement. ${ }^{95}$ Also many NGOs are themselves involved in a similar effort of independent standardisation regarding their internal organisation.

Imposing democratic norms on NGOS is often understood as an attempt to assess and ensure NGOs trustworthiness. ${ }^{96}$ Trust is a fundamental element of legitimacy. ${ }^{97}$ Therefore trust in international law, because NGOs are involved in the making of it, inherently implies trust in NGOs, which must be grounded. However, there is evidently a difference between applying standards to prevent NGOs from engaging in wrongdoing, corruption, or illicit behaviour, ${ }^{98}$ and requiring an NGO to be organised in the way 'we' think an NGO should be organised. ${ }^{99}$ When standards are imposed on NGOs, they are pushed towards becoming particular organisations they might just not be, want to be, or have

95 The scholarly tendency to focus on NGOs organisation can be mirrored with the institutional practice of the accreditation mechanisms. Ecosoc Resolution 1996/31 mentions strong endogenous requirements towards the organisations that require consultative status (see para. 10, 11, and 12). Interesting in this regard is the fact that European rules on accreditation deliberatively leave aside the requirement of democratic adopted constitutions for NGOs. Participatory Status for International Non-Governmental Organisations with the Council of Europe, Resolution (2003) 8 of 9 November 2003 (COE 2003, para. 33 and 55).

96 Jan Klabbers, An Introduction to International Institutional Law (2005) p. 341.

97 Legitimacy is based on the belief of broad sections of the population that political institutions and their equipage are worthy of trust. Weber calls it "Legitimitätsglaube". Weber put forward a sociological account of legitimacy that focuses primarily on faith, and excludes normative criteria. Weber distinguishes three main sources of legitimacy: tradition, charisma and legal rationality. Max Weber, The Theory of Social and Economic Organisation (1964) p. 382.

98 These standards are often part of the preconditions of NGOs to obtain legal personality at the domestic level.

99 The complexity of the issue of for example demanding democratic accountability of NG Os is convincingly shown by Slim. Slim, supra note 53, p. 8. 
the intention of being. Prescribing and regulating their mode of decisionmaking and operation might undermine the specific purpose of NGOS, and the values based on which they pursue their activities. ${ }^{100}$

There is a fine line between NGOs maintaining their usefulness towards governmental organisations, which increases their chances of participating in international law-making, and maintaining their own identity and independence. To prevent NGOs from becoming the fourth arm of governmental organisations, one should abstain from too many regulations. Any formulated requirement by the international organisation concerning the internal organisation of NGOs would lead to the undesirable situation in which the demandidentity of international organisations or states is unilaterally made a decisive factor for the form, function, and characteristics of an NGO. Consequently, social-political conceptions will start to function as a substitute for the specific purpose-relevant identity of an association initiated by citizens.

Besides, undeniably attached to, and reflected in NGOs' work, is their vision of humankind and its place in society. The imposition of democratic norms requires an adaptation of democratic decision-making that subsequently leads to the arbitrary interchangeability of their vision of life and politics. Such interchangeability is, in the case of governmental actors, the primary reason to democratise them because it gives individuals the opportunity to equally steer the course of government and to prevent them being subjected to unwanted domination. However, in the case of NGOS one can argue that such subjection to democratic norms about decision-making might, in effect, be more intolerant than accepting NGOs' openly marketed signature. These remarks touch upon a whole complex of issues concerning the difficulty of striking a balance between integrity, independence, the financial support of NGOS, and interference by other actors that one can trace back to the NGO democratic legitimacy debate that will not be further discussed at this stage. ${ }^{101}$ My main aim here is to show the possible risks of ascribing content-independent standards to content-driven actors, which is what NGOs ultimately are.

\footnotetext{
100 As Charnovitz states: "In my view, Pope Leo XIII was right when he warned that the state 'should not thrust itself' into societies and citizens banded together in accordance with their rights. Governmental bureaucrats and politicians do not have any special competence to oversee NGO politics and guide them towards attainment of the common good." Charnovitz, supra note 5 , p. 33 .

101 See for a discussion on these liberal democratic expectations towards associations, Victor Muñiz-Fraticelli, The Structure of Pluralism, On the authority of Associations (2014) p. 245, referring to Rosenblum. Rosenblum considers the hope false and dangerous that "the character of all organisations could be reshaped to conform with principles of liberal and democratic legitimacy". Rosenblum, supra note 93, pp. 36-42, pp. 57-6o.
} 


\section{$7 \quad$ Questionable Merits of using Content-independent Terms}

Besides the scholarly desire to place NGOs under content-neutralising government-like procedures, one can also notice a theoretical tendency to explain NGOs as actors that contribute to a detached conception of democracy. ${ }^{102}$ Scholars suggest that NGOs' involvement brings inclusiveness, and representation. ${ }^{103}$ The proposed manifestations of NGOS as facilitators of the public sphere and as representatives are presented as content-independent roles that manifest the interests and the will of citizens. These concepts and manifestations are related to the so-called input legitimacy.

Such a presentation of NGOs leads to the assumption that regardless of what opinion is formed by individuals or groups, NGOs facilitate the formulation of opinions, the provision of information, and the mobilisation of individuals to think, speak, and discuss, and enable the representation of opinions on the international stage. The extent to which NGOs make the legislative process inclusive and contribute to the legitimacy of input, which one assumes to be neutral with regard to the interests and groups and individuals represented by NGOS, is in practice, however, often directly or indirectly associated with the content of the message of the NGO. This, contrary to the suggestions made, implies a dependent conception of democratic legitimacy, focusing on the output of law-making. ${ }^{104}$ There is apparently a gap between these common contentneutral, procedural expectations and the reality of the motives of governmental actors to include NGOS in international legislative practices, which can be, in most cases, traced back to the primary value of NGOs' substantive input. Although I have not undertaken empirical studies to substantiate this assumption, one finds support in, for example, the requirements of the accreditation procedure of ECOSOC that states that the work of NGOs should be in line with the objectives of the UN. ${ }^{105}$

I am not the first to challenge this tendency. Peters refuted the often-heard claim of opponents of the thesis that an undemocratic internal organisation of

\footnotetext{
102 Ronald Dworkin, Sovereign Virtue: The theory and practice of equality (2000) p. 186.

103 Nerfin, supra note 37, pp. 54-57; Susan Marks, The Riddle of All Constitutions: International Law, Democracy, and the Critique of Ideology (2000) pp. 113-114.

104 See Thomas Kelley, "Wait! That's Not What We Meant by Civil Society: Questioning the N Go Orthodoxy in West Africa", 36(3) Brooklyn International Law Review (2010).

105 See ECOSOC, Resolution 1996/31, E/RES/1996/31, July 25, 1996 (Consultative relationship between the United Nations and non-governmental organisations), principle 2: "The aim and purpose of the organisation shall be in conformity with the spirit, purposes and principles of the Charter of the United Nations".
} 
NGOs should lead to the conclusion that they cannot contribute to the overall democratic legitimacy of international law. According to Peters, the relative uncertainty about the democratically legitimate character of NGOS should not lead to a strict appraisal of their internal legitimacy, but should lead to the conclusion that NGOS are limited to a voice in law-making processes, not to a vote, which is the case in practically all of the international organisations. ${ }^{106} \mathrm{~A}$ voice might be sufficiently justified by the reputation and moral compass of NGOS, and does not need to be backed up by democratic procedures. ${ }^{107}$

Further, notwithstanding the use of content-independent terminology, the scholarly work in favour of the thesis implicitly reveals the tendency to connect NGOs with a subjective level of goodness. ${ }^{108}$ An example is Charnovitz's exploration of NGOs in which he focuses on the procedural democratic contributions of NGOs and at the same time views NGOs as correctors "for the pathologies of governments and IOs".109 Other scholars envision the global civil society in which NGOs take part as a 'solidarity sphere', where all are working towards "progressive transformation through collective association". ${ }^{110}$ NGOS are '"called upon to serve the 'developmental' function of moulding the habits and attitudes of their members in the direction of overall cooperation"."11 These scholars expect a commitment of NGOs to finding acceptable terms of international political cooperation. This however requires a consensus of reasonably comprehensive views, and there seems to exist a certain underlying bias in defining what can be understood as 'reasonably comprehensive'.

106 An exception is the International Labour Organisation, the only tripartite UN agency.

107 Peters states: "It is precisely a feature of pluralist law-making processes to offer interest groups the opportunity to participate and give input into the process without requiring any democratic mandate". As Peters concludes, "democratic legitimacy of NGO voice does not require representativity in terms of a democratic mandate conferred by a (more or less virtual) global society". Anne Peters, "Dual democracy", in J. Klabbers, A. Peters and G. Ulfstein (eds.), The Constitutionalization of International Law (2009) p. 317.

108 In an attempt to explain the bias towards the 'good' in scholarly writing concerning NG Os, Amoore and Langly link this tendency to the "continuing relevance of Marxist thought. "Just as the proletariat is juxtaposed to the bourgeoisie under Marxism, scholars of GSC (red: Global Civil Society) position the 'good' of civil society against the 'bad' of state and capital". Amoore and Langly, supra note 76, p. 96, referring to John Keane, "Global Civil Society?”, in H. Anheier, M. Glasius, and M. Kaldor (eds.), Global Civil Society (2001) p. 30.

109 Charnovitz's selection of seven main tasks of NGOs is exemplary. See Charnovitz, supra note 33, pp. 894-895.

110 Amoore and Langly, supra note 76, p. 92, referring to Jeffrey Alexander, "The Paradoxes of Civil Society", 12(2) International Sociology (1997) pp. 115-133.

111 Barnard, supra note 75, p. 149, referring to George Cole, "Conflicting Social Obligations", 15 Proceedings of the Aristotelian Society (1915) p. 158. 
The terms and words used by the proponents of the NGO democratic legitimacy thesis refer to value-laden perceptions of what is supposedly good or bad. This is difficult to rhyme with their inclination towards understanding NGOs' participation as a contribution to the democratic legitimacy of international law that, to the contrary, suggests a preference for opening up the political space to individuals to decide for themselves what is good or bad. Besides, not all NGOs are good. Sometimes it seems that academics involved in the NGO democratic legitimacy debate have a blind spot with regard to the miscellaneous manifestations of NGOs and civil society. ${ }^{12}$ To construct a suitable theory of democratic legitimacy with the NGO as the dominant building block, there is a risk that scholars select specific NGOs that fit their theoretical mind-set, while leaving out others. ${ }^{13}$

Four grounds strengthen the assumption that there is a strong relation between accepting NG OS and the content of their message. Firstly, any accreditation system indirectly encourages the involvement of the ones that are activists by nature, the ones that feel engaged to influence international law-making. ${ }^{114}$ Secondly, with regard to the legal framework for involvement, one discovers that the international governance seems to be conceptualised as 'working together' for the common good. ${ }^{115}$ Thirdly, the NGOs that are predominantly active in what from a Western perspective would be labelled normatively desirable working areas, such as human rights and environmental law, seem to play a major role in the theory of NGOs' contribution to the democratic legitimacy of international law. Fourthly, a link is often presumed between NGOS and democratic legitimacy when NGOs help specific minority groups with voicing their issues, for example indigenous peoples. ${ }^{116}$

112 As Klabbers states, "[w]hile we expect our statesmen to be democrats, and while we try to sell the blessings of it to those that have hitherto remained deprived of democracy, we simultaneously allow our spirits to be uplifted by the utterly undemocratic politics of civil society, conveniently ignoring the circumstance that civil society not only includes our noblest dreams, but may also include our worst nightmares". Klabbers, supra note 96 , p. 341.

113 Pedraza-Fariña has made a convincing point and theory to respond to the diversity of scholarly conceptions and scholarly expectations of civil society. Laura Pedraza-Fariña, supra note 78, p. 654 .

114 Johns, supra note 45, p. 2.

115 As mentioned, Ecosoc is explicit about the requirements of admission and accreditation; the aims of the NGO should be in line with the mission of the UN.

116 Cox states that the possible implication of a biased focus on goodness is that the dark forces' of extreme right, terrorists, organised crime, and intelligence service remain out of sight, while at the same time further enjoying their 'covert power'. Robert Cox, "Civil 
Although a content-independent vocabulary is used the participation of NGOs seems to be predominantly appreciated for their substantive contribution (expertise, standards of justice, ability to protect the minority interest). As Pasha and Blaney point out, "NGOs in their most exalted form (and there are many hybrid exceptions) exist to convince people of the rightness of their ideals and invite people to become constituents of those ideals, not to advocate for whatever ideals people already happen to have". 117 NG Os' wider legitimacy seems to be morally derived, more than politically derived, and has exclusive characteristics. ${ }^{118}$ Most NGOs are driven by specific values, the desire to work not-for-profit, voluntarily, and for, in their specific views, a better society. ${ }^{119}$ A content bias towards NGOs' 'goodness' is therefore in itself intelligible. However, such a bias should simultaneously be reflected in any understanding of NGOs' contribution to international law-making.

In sum, the validity of imposing democratic norms on the organisation of NGOS as prerequisite for understanding their contribution as democratically legitimising international law is questionable on different grounds. First, one cannot formulate ante hoc expectations of NGOS, due to their inherent dynamic and prismatic character, which underscores their unpredictability in organisational structure and behaviour. Second, externally subjecting NGOS to democratic governing structures, which is often suggested as a response to the criticism of NGOs' lack of representation, negatively affects the inherent voluntariness of NGOs. Third, there is a mismatch between the scholarly inclination to describe NGOs in procedural content-independent terms such as representation, transparency, or inclusion, whereas practice and legal documents suggest that NGOS are primarily valued for their content-dependent contributions. There is a fourth objection to make against the scholarly tendency to prioritise NGOs' internal democratisation, which will be discussed in the concluding section. Prioritising NGOs' democratisation over the democratisation of the international law-making processes leads to the paradoxical situation in which NGOs are required to be internally democratised, but there is little attention paid to the lack of opportunities for democratic agency in international law-making.

Society at the Turn of the Millennium: Prospects for an Alternative World Order", 25(1) Review of International Studies (1999) pp. 13-15.

117 Kenneth Andersson and David Reiff, "Global Civil Society, A Skeptical View", in H. Anheier, M. Glasius, M. Kaldor (eds.), Global Civil Society (2004-2005) p. 5.

118 Mustapha Pasha and David Blaney, "Elusive Paradise: The Promise and Peril of Global Civil Society", 23(4) Alternatives: Global, Local, Political (1998) p. 423.

119 Brandsen, Van de Donk and Putters, supra note 93, p. 760. 
The criticism on NGOs' accountability is closely tied to an understanding of NGOs as democratic representatives of groups of peoples. ${ }^{120}$ To question the democratic legitimacy of NGOs based on the lack of accountability mechanisms is really to ask whether NGOs are representative of those they claim (or once claimed) to represent. ${ }^{121}$ In this light, it seems obvious that NGOs need to prove the existence and support of their alleged constituency. However, only a particular political conduct requires such a relationship between a political actor and a forum (constituency): the democratic exercise of public authority. ${ }^{122}$ Democratic accountability regulates the exercise of public authority by subjecting its exercisers to constitutional, legal, and administrative norms to ensure that the activities of representatives are both legally and politically accountable. ${ }^{123}$ Demanding NG Os' accountability as a precondition for their democratically legitimising role suggests that there is a political role to play for NG Os in international law-making.

The requirement of NGOs' democratic legitimacy seems to be a matter of erroneous prioritisation. Although I have refuted the relevance of democratic norms for NGOS in the previous sections, even if relevant, the question of the democratic legitimacy of NGOs can only become appropriate when one is assured that the system in which NGOs are involved offers actual opportunities to democratically legitimise law-making. Thus scholars pleading for an internal democratic legitimation of NGOs should at least equally engage in theorising a political space for NGOs to be able to function as political representatives (apart from the question whether such function would fit NGOs). ${ }^{124}$ Remarkably, scholars who criticise NGOs for their lack of democratic

\footnotetext{
120 Peruzzotti, supra note 4, p. 164.

121 This is in stark contrast with the way accountability is a practical matter for states to participate. According to Spiro: "Governments can get away with an awful lot before having to answer to their membership, and yet of course that has supplied no argument against their participation in international institutions". Spiro, supra note 3, p. 164, referring to the fact that not even democracy is in practice seen as a precondition.

122 Erika De Wet, "Holding International Institutions Accountable: The Complementary Role of Non-Judicial Oversight Mechanisms and Judicial Review", in A. Von Bogdandy et al. (eds.), The Exercise of Public Authority by International Institutions. Advancing International Institutional Law (2010) p. 1988; Eva Erman, "In search of democratic agency in deliberative governance", European Journal of International Relations (2012) p. 16.

123 Peruzzotti, supra note 4, pp. 159-16o.

124 See for a comparable argument: Peruzzotti, supra note 4, pp. 166-167.
} 
accountability rarely address the question of whether NGOs have sufficient rights and means to be in the position to truly represent individuals.

As practice and legal documents regarding the accreditation mechanisms taught us, NGOs have no means to engage in decision-making. Take for example the coming into existence of the Ottawa Landmine Convention that in many scholarly works functions as an illustration of what power of NGOS can bring about. ${ }^{125}$ The Convention gained 122 country signatures when it opened for signing on 3 December 1997 in Ottawa, Canada. Thirty-five countries have not signed the treaty, including a majority of the permanent members of the United Nations Security Council: China, the United States and Russia. Although the norm creation by different coalitions of NGOs is an inspiring example of what the bundling of social power can achieve, it cannot be equated with the exercise of political power. ${ }^{126}$

We should make a clear analytical distinction between what is desired and what is required of NGOs from a democratic legitimacy perspective. The substantive impact of NGOS on the political course of international law-making is in some instances huge which intuitively leads to a desire for democratic accountability. However, any influence of NGOs on international law-making is conditional upon the goodwill of states. The non-existent room for the exercise of political power by NGOS in international law-making makes it simply redundant to subject NGOS to strict, general appraisal of their democratic accountability structure. ${ }^{127}$

This article obviously invokes many underlying, theoretically challenging, questions. Could the international legal order ever provide the institutional and social preconditions necessary to enable any form of democratic agency? Is democratic legitimacy as such a reasonable concept to evaluate international law? Notwithstanding the apparent daunting task to find answers to them, these pressing concerns require our attention first. Scholarly uncertainty towards the question how to democratically legitimise international law should not lead to the imposition of democratic norms on NGOs. Striving for an equal

\footnotetext{
125 Convention on the Prohibition of the Use, Stockpiling, Production and Transfer of AntiPersonnel Mines and on their Destruction, Sept. 17, 1997, I-35597 U.N.T.S. 2056.

$126<$ https://treaties.un.org/pages/showDetails.aspx?objid=0800000280006d6o > (last visited June 2017).

127 This does not exclude the possible demand of members of specific NGOs to be accountable internally or externally. Instead of a general obligation to be accountable, this would be a voluntary member-based decision that its organisation must fulfil certain requirements.
} 
assessment and representation of interests is not the task of NGOs but of the exercisers of public authority. In most cases, NGOs have been founded precisely to counter the will of the majority, and to act as opposition. Externally imposed democratic norms obstruct the function of NG O to pursue one single issue, value or special interest. 